\title{
PERUBAHAN PREMIUM INCOME DAN INVESTMENT RESULTS PT. AXA MANDIRI SYARIAH DAN IMPLIKASINYA TERHADAP TABARRU FUND RESERVE
}

\author{
Wilda Waladiah Ibnu Suja'i \\ Perbankan Syariah, STIBANKS AI-Ma'soem Bandung \\ wildaibnusuja@gmail.com \\ Badriyatul Huda \\ Perbankan Syariah, STIBANKS AI-Ma'soem Bandung \\ badriyatulhuda123@gmail.com
}

\begin{abstract}
This paper is motivated by a phenomenon shows that the Premium Income and Investment Results at PT. AXA Mandiri Syariah experiences fluctuations, both of which have a direct impact on the condition of the Tabarru Fund Reserve. Therefore, this article aims to analyze the effect of official income and investment hail on tabarru fund reserves both partially and simultaneously. This article also uses descriptive methods and quantitative approaches, namely to describe the results of the research, the data of which are presented in numerical form. The data in this article is secondary data taken from the financial statements of PT. AXA Mandiri Syariah and supported by literature study and documentation, which are processed statistically and quantitatively. The results of this study concluded that Premium Income has a significant effect on the Tabarru Fund Reserve by $100 \%$. Then, the investment return also bas a significant effect on the Tabarru Fund Reserve by $88.4 \%$. Finally, both simultaneously have a significant effect on the Tabarru Fund Reserve by 100\%. The implication of this research is that insurance companies need to increase Premium Income and Investment Results because both have a significant effect on increasing the Tabarru Fund Reserve.
\end{abstract}

Keywords: Premium Income, Investment Result, Tabarru Fund Reserve, Islamic Insurance

\begin{abstract}
Abstrak
Tulisan ini dilatarbelakangi fenomena yang menunjukan bahwa Premium Income dan Investment Results pada PT. AXA Mandiri Syariah mengalami fluktuasi yang mana keduanya berdampak langsung kepada kondisi Tabarru Fund Reserve. Oleh karena itu, artikel ini bertujuan untuk menganalisis pengaruh pendapatan presmi tersebut dan hail investasi terhadap cadangan dana tabarru baik secara parsial dan simultan. Artikel ini juga menggunakan metode deskriptif dan pendekatan kuantitatif, yakni untuk mendeskripsikan hasil penelitian yang datanya disajikan dalam bentuk numerik. Data pada artikel ini merupakan data sekunder yang diambil dari laporan keuangan PT. AXA Mandiri Syariah dan didukung dengan studi kepustakaan dan dokumentasi, yang diolah scara statistik dan kuantitatif. Hasil penelitian ini menyimpulkan bahwa Premium Income berpengaruh signifikan terhadap Tabarru Fund Reserve sebesar 100\%. Lalu, hasil investasi juga berpengaruh signifikan terhadap Tabarru Fund Reserve sebesar 88,4\%. Terakhir, secara simultan keduanya juga berpengaruh signifikan terhadap Tabarru Fund Reserve sebesar 100\%. Implikasi dari penelitian ini adalah perusahaan asuransi perlu meningkatkan Premium Income dan Investment Results, karena keduanya berpengaruh signifikan untuk meningkatkan Tabarru Fund Reserve
\end{abstract}

Kata kunci: Premium Income, Investment Result, Tabarru Fund Reserve, Islamic Insurance 


\section{Pendahuluan}

Di era modernitas ini, kehidupan berkembang ke arah yang lebih kompleks, sehingga menimbulkan risiko dan dampak yang mungkin terjadi secara tidak terduga dimasa yang akan datang. Manusia dituntut untuk selalu berantisipasi dalam menjaga diri, keluarga dan orangorang terdekat baik itu dari aspek kehidupan, kesehatan, maupun pendidikan untuk masa depan anak cucu kelak. Oleh karena itu, setiap manusia membutuhkan jaminan yang akan membantu dalam meminimalisir terjadinya risiko dimasa mendatang. Di Indonesia, terdapat sebuah lembaga yang memberikan jaminan atas kekhawatiran tersebut dan dapat menjadi alternatif solusi bagi masyarakat, lembaga tersebut disebut perusahaan asuransi.

Perusahaan asuransi di Indonesia ada dua yaitu asuransi syariah dan asuransi konvensional. Secara definitif, asuransi ialah perjanjian tertulis antara pihak asuransi dengan penerima asuransi yang bersifat mengikat, dimana penerima asuransi mendapatkan penggantian berupa premi suatu kerusakan, kehilangan, kerugian, yang tidak diinginkan dan terjadi pada waktu yang tidak dapat ditentukan (Mulyawan, 2015). Sedangkan, asuransi syariah pada dasarnya sejalan dengan definisi di atas hanya saja menurut Muhaimin Iqbal, asuransi syariah terdiri dari dua unsur yaitu peserta dan operator yang melakukan pengelolan risiko dengan mengikuti ketentuan syariah dan bersifat tolong menolong (Iqbal, 2005).

Terdapat perbedaan diantara keduanya, seperti asuransi syariah membangun brand imagenya sebagai asuransi yang berorientasi sosial (social oriented) sedangkan asuransi konvensional berfokus pada keuntungan atau profit oriented. Perbedaan mendasar ini dikarenakan dalam asuransi syariah menggunakan prinsip at-ta'awun (Sumato \& dkk, 2009). Selain itu, perbedaan lainya menurut Muhaimin Iqbal (2005) adalah pengelolaan dan penanggungan risiko kemudian pengelolaan dana asuransi yang disimpan oleh pihak tertanggung. Kemudian, penyebutan antara pihak asuransi dan penerima asuransi, pada asuransi konvensional disebut penanggung dan tertanggung, sedangkan pada asuransi syariah disebut operator dan peserta (Iqbal, 2005).

Layaknya asuransi konvensional, asuransi syariah juga memiliki komponen serupa di dalamnya, dana tabarru, pendapatan premi, total beban asuransi, hasil atas investasi, dan kelebihan (surplus) underwriting. Dana tabarru' sendiri diartikan secara sumbangan sukarela yang dari seseorang kepada orang lain, tanpa imbal balik, yang berakibat pada pemindahan hak milik harta dari pemberi dana tabarru kepada penerimanya, yang kemudian harus dicadangkan guna kepenting pada waktu tertentu.

Kenaikan dan penurunan cadangan dana tabarru ini dipengaruhi oleh banyak faktor, diantaranya pendapatan premi (premium income) dan hasil investasi (investment result). Pendapatan premi (premiun income), yang mana dalam asuransi konvensional merupakan pembayaran polis asuransi dalam bentuk sejumlah uang oleh pemilik asuransi kepada perusahaan asuransi dikarenakan terdapat perjanjian pertanggungan yang ditulis dalam perjanjian polis asuransi dikutip dari (Ali, Subekti, \& Wardana, 1996). Dalam teorinya, pendapatan premi yang telah dibayarkan oleh pemegang polis dikumpulkan ke dalam dana tabarru' untuk dikelola oleh pihak asuransi. Dana yang dibayarkan oleh pemilik asuransi kepada perusahaan merupakan premi asuransi dan reasuransi yang telah dikurangi ujrah (sewa) dan fee (upah) yang selanjutnya disebut pendapatan bagi pihak perusahaan asuransi. Berikutnya, selain dipengaruhi oleh pendapatan premi dana tabarru juga dipengaruhi oleh hasil investasi. Investment Results atau hasil investasi adalah hasil yang didapatkan dari dana tabarru' dan tabungan yang dikelola oleh perusahaan asuransi. 
Dana tabarru merupakan hasil akumulasi yang terbentuk dari akumulasi cadangan surplus/defisit dana tabarru, donasi, hasil investasi yang kemudian disalurkan kembali ke dalam dana tabarru, hal ini sejalan dengan PSAK No. 108 tentang Akuntansi Transaksi Asuransi Syariah. Maka dari itu, apabila premium income (pendapatan premi) meningkat dan investment results (hasil investasi) juga meningkat maka akan berdampak pada cadangan dana tabarru yang juga bertambah karena dana tabarru menjadi surplus dan banyak yang bisa di cadangkan.

Salah satu perusahaan asuransi di Indonesia yang memiliki produk dalam bentuk syariah adalah PT. AXA Mandiri Syariah. Seiring perkembangannya yang cukup lambat dan usianya yang masih baru maka banyak juga kendala yang dihadapi, seperti masyarakat yang minim pengetahuan terkait asuransi syariah, yang sebenarnya merupakan kebutuhan penting dimasa mendatang, juga banyak perusahaan pendatang dalam bidang asuransi syariah dan non syariah yang menawarkan fitur lebih menarik bagi masyarakat. Namun berdasarkan data laporan keuangan yang telah diterbitkan, peneliti menemukan bahwa cadangan dana tabarru terus meningkat sejak 2015 hingga 2019. Seperti yang telah dijelaskan, bahwa banyak faktor yang mempengaruhi pembentukan dana tabarru dan pencadangannya, maka penelitian ini akan berfokus pada perubahan premium income dan investment result yang diduga mempengaruhi peningkatan secara stabil dari tabarru fund reserve.

\section{Metode}

Paper ini menggunakan metode deskriptif dalam penelitiannya, kemudian karena penelitian adalah jenis kuantitatif maka pendekatan penelitian dalam artikel ini adalah kuantitatif. Peneliti menggunakan bantuan software SPSS untuk mengetahui hasil akhir mengenai pengaruh atau tidaknya penelitian ini, dan teknis analisis data yang digunakan adalaj uji kuantitatif yang terdiri dari analisis regresi, uji hipotesis, uji kekuatan hubungan dengan R Square dan korelasi Pearson Product Moment. Data diperoleh dari laporan keuangan yang telah diterbitkan secara terbuka oleh PT. AXA Mandiri Syariah Periode 2015-2019. Data dalam paper ini diperoleh dengan studi kepustakaan, dokumentasi, observasi, dan wawancara.

\section{Hasil dan Pembahasan}

\subsection{Perubahan Premium Income dan Implikasinya terhadap Tabarru Fund Reserve}

Dalam operasional asuransi syariah yang menjadi sumber pendapatannya adalah pendapatan premi (premium income). Peserta asuransi diwajibkan membayarkan sejumlah uang pada jumlah tertentu sesuai akad secara berkala sesuai waktu yang disepakati, ini dinamakan premi. Uang tersebut yang menjadi pendapatan premi bagi perusahaan asuransi syariah. Besar kecilnya pembayaran premi dari peserta asuransi dapat dilihat dari tinggi atau rendahnya risiko dan nilai pertanggungan (Lestari, 2017). Maka dari, menurut hemat peniliti pendapatan premi ini merupakan faktor terbesar yang membentuk cadangan dana tabarru' perusahaan asuransi. Maka manajemen underwriting perlu menyusun strategi penetapan premi yang adil namun menguntungkan kedua pihak.

Hubungan premium income dengan tabarru fund reserve dapat dijelaskan dengan peserta asuransi yang berumur lebih tinggi akan berdampak pada nilai tabarru karena semakin panjang perjanjian polis asuransi yang dibayar. Hal ini dapat diartikan,semakin tinggi premi yang 
didapatkan maka dana yang diinvestasikan besar dan berdampak pada laba dan cadangan dana tabarru yang semakin besar (Sula, 2004).

Merujuk pada teori di atas, tenyata pada penelitian ini Premium Income memiliki pengaruh terhadap Tabarru Fund Reserve PT. AXA Mandiri Syariah. Hasil penelitiannya adalah:

Tabel 2 Hasil Uji Regresi Linear dan Uji t Pengaruh Premium Income terhadap Tabarru Fund Reserve

Coefficients $^{\mathrm{a}}$

\begin{tabular}{|rl|r|r|r|r|r|}
\hline \multicolumn{2}{|l|}{ Model } & \multicolumn{2}{|c|}{ Unstandardized Coefficients } & \multicolumn{1}{c|}{$\begin{array}{c}\text { Standardized } \\
\text { Coefficients }\end{array}$} & \multicolumn{1}{c|}{ Sig. } \\
\cline { 3 - 6 } & \multicolumn{1}{|c|}{$\mathrm{B}$} & Std. Error & \multicolumn{1}{c|}{ Beta } & \\
\hline \multirow{2}{*}{1} & (Constant) & -2.389 & 1.883 & & -1.269 & .221 \\
& Premium_Income & .150 & .000 & 1.000 & 920.107 & .000 \\
\hline
\end{tabular}

a. Dependent Variable: Tabarru_Fund_Reserve

Sumber: output SPSS versi 20

Berdasarkan tabel di atas diperoleh persamaan:

Tabarru FundR eserved $=-2,389+0,150$ Premium Income

Didasarkan atas persamaan regresi tersebut, bisa dijelaskan apabila nilai $\mathrm{X}_{1}$ (Premium Income) bernilai nol, maka Y (Tabarru Fund Reserve) bernilai -2,389. Sementara itu, jika $\mathrm{X}_{1}$ (Premium Income) berubah sebesar 1 (satu) satuan, maka akan memberikan dampak pada peningkatan terhadap Y (Tabarru Fund Reserve) sebesar 0,150. Selanjutnya, persamaan regresi linear sederhana tersebut memperlihatkan bahwa Premium Income berpengaruh positif terhadap tabarru fund reserve.

Pengaruh Premium Income dalam mempengaruhi kenaikan dan penurunan Tabarru Fund Reserve dapat dilihat dari hasil uji $t$. Dari tabel di atas interpretasinya adalah $t$ tabel sebesar 920,107 dengan signifikansi 0,000. Hal ini memenuhi syarat thitung $>t_{\text {tabel }}(920,107>2,10092)$ dengan nilai taraf signifikansi sebesar 5\%. Hasil tersebut berarti Premium Income memiliki pengaruh yang signifikan terhadap Tabarru Fund Reserve.

Selanjutnya kekuatan hubungan dan kontribusi pengaruh Premium Income terhadap Tabarru Fund Reserve dapat dilihat pada tabel berikut

\section{Tabel 3 Hasil Uji Korelasi dan Koefisien Determinasi}

Model Summary

\begin{tabular}{|l|r|r|r|r|}
\hline Model & \multicolumn{1}{|c|}{$\mathrm{R}$} & \multicolumn{1}{c|}{ R Square } & Adjusted R Square & $\begin{array}{c}\text { Std. Error of the } \\
\text { Estimate }\end{array}$ \\
\hline 1 & $1.000^{\mathrm{a}}$ & 1.000 & 1.000 & .99734 \\
\hline
\end{tabular}

a. Predictors: (Constant), Premium_Income

Sumber: hasil output SPSS versi 20

Berdasarkan perhitungan statistik di atas dapat diketahui besarnya hubungan Premium Income terhadap Tabarru Fund Reserve adalah 1,000 dimana berada pada kriteria sangat kuat. Dan $\mathrm{R}$ Square $\left(\mathrm{r}^{2}\right)$ menunjukkan nilai koefisien determinasi, besarnya $\mathrm{r}^{2}$ adalah 1,000 atau sama dengan 100\%. Hal ini berarti Premium Income mampu menjelaskan pengaruhnya terhadap Tabarru Fund Reserve sebesar $100 \%$.

Hasil penelitian ini sejalan dengan teori yang dikemukakan oleh Sula (2004), dimana kontribusi yang merupakan kata lain dari premi dalam asuransi memberikan efek langsung dalam kenaikan atau penurunan underwriting atau dana tabarru. Premi dalam asuransi syariah 
dibagi menjadi dua yang pemilihannya ditentukkan saat akad keduanya adalah dana tabungan dan dana tabarru'. Maka yang mempengaruhi langsung underwriting adalah kontribusi neto atau premi neto dimana dana yang dibayarkan awal oleh peserta asuransi dikurangi dengan bebanbeban (Sula, 2004). Jadi, saat premi PT. AXA Mandiri Syariah meningkat maka kontribusi netonya meningkat dan mempengaruhi cadangan dana tabarru yang juga bertambah.

\subsection{Perubahan Investment Result dan Implikasiynya terhadap Tabarru Fund Reserve}

Investasi merupakan penanaman modal pada portofolio efek tertentu. Tujuan utama dari investasi ini tentu selain menjaga aset juga ditujukan untuk mendapatkan return atas investasi yang maksimal, dengan risiko yang minim. Return atas investasi disebut juga hasil investasi, yang mana didapatkan dari beragam portofolio efek yang diinvestasikan, guna mendapatkan nisbah bagi hasil yang baik. Maka dari itu hasil investasi menjadi faktor penting bagi pendapatan asuransi syariah (Sula, 2004).

Investment Result atau hasil investasi pada asuransi syariah adalah hasil yang diperoleh dari dana peserta berupa dana tabarru' dan tabungan yang dikelola perusahaan asuransi sebagai pengelola. Hasil investasi ini akan menambah saldo akun Dana Peserta di Laporan Surplus Defisit Underwritting sebelum dikurangi dengan hak pengelola sebagai mudharib (Bayinah \& dkk, 2017).

Merujuk pada teori di atas, tenyata pada penelitian ini investment result memiliki pengaruh terhadap Tabarru Fund Reserve PT. AXA Mandiri Syariah, Hasil penelitiannya adalah:

\section{Tabel 4 Hasil Uji Regresi Linear dan Uji $t$}

Coefficients $^{\mathrm{a}}$

\begin{tabular}{|rl|r|r|r|r|r|}
\hline \multicolumn{2}{|l|}{ Model } & \multicolumn{2}{|c|}{ Unstandardized Coefficients } & $\begin{array}{c}\text { Standardized } \\
\text { Coefficients }\end{array}$ & \multicolumn{1}{c|}{$\mathrm{t}$} & \multirow{2}{*}{ Sig. } \\
\cline { 2 - 7 } & \multicolumn{1}{|c|}{$\mathrm{B}$} & Std. Error & \multicolumn{1}{c|}{ Beta } & & \\
\hline \multirow{2}{*}{1} & (Constant) & -101.271 & 155.893 & & -.650 & .524 \\
& Investment_Result & .144 & .012 & .940 & 11.734 & .000 \\
\hline
\end{tabular}

a. Dependent Variable: Tabarru_Fund_Reserve

Sumber: hasil output SPSS versi 20

Persamaan yang didapatkan dari hasil SPSS di atas adalah:

\section{Tabarru Fund Reserve $=-101,271$ 0,144 Investment Result}

Didasarkan atas persamaan regresi tersebut, bisa dijelaskan apabila nilai $\mathrm{X}_{2}$ (Investment Result) bernilai nol, maka Y (Tabarru Fund Reserve) bernilai -28,078. Sementara itu, jika $\mathrm{X}_{2}$ (Investment Result) berubah sebesar 1 (satu) satuan, maka akan memberikan dampak pada peningkatan terhadap Y (Tabarru Fund Reserve) sebesar 5,290. Selanjutnya, persamaan regresi linear sederhana tersebut memperlihatkan bahwa Investment Result memiliki arah pengaruh yang positif terhadap Tabarru Fund Reserve.

Pengaruh inflasi terhadap Tabarru Fund Reserve dapat dilihat dari hasil uji $t$ dimana hasil di atas tidak memenuhi kriteria berpengaruh karena 1,208 $<2,306$ dengan Sig. 0,262 > 0,05. Sehingga peneliti terhadap Tabarru Fund Reserve PT. AXA Mandiri Syariah, Tbk. periode 20102019 mendapatkan hasil akhir bahwa Investment Result memiliki pengaruh

Selanjutnya kekuatan hubungan dan kontribusi pengaruh Investment Result terhadap Tabarru Fund Reserve dapat dilihat pada tabel berikut: 
Tabel 5 Hasil Uji Korelasi dan Koefisien Determinasi Model Summary

\begin{tabular}{|c|c|c|c|c|}
\hline Model & $\mathrm{R}$ & $\mathrm{R}$ Square & Adjusted R Square & $\begin{array}{c}\text { Std. Error of the } \\
\text { Estimate }\end{array}$ \\
\hline 1 & $.940^{\mathrm{a}}$ & .884 & .878 & 73.54847 \\
\hline
\end{tabular}

a. Predictors: (Constant), Investment_Result

Sumber: hasil output SPSS versi 20

Berdasarkan perhitungan statistik di atas dapat diketahui besarnya hubungan Investment Result terhadap Tabarru Fund Reserve adalah 1,000 dimana berada pada kriteria sangat kuat. Dan $\mathrm{R}$ Square $\left(\mathrm{r}^{2}\right)$ menunjukkan nilai koefisien determinasi, besarnya $\mathrm{r}^{2}$ adalah 0,884 atau sama dengan 88,4\%. Hal ini berarti Investment Result mampu menjelaskan pengaruhnya terhadap Tabarru Fund Reserve sebesar 88,4\%, sedangkan sebesar 11,6\% dipengaruhi oleh faktor lainnya.

Merujuk pada hasil penelitian di atas, ternyata sejalan dengan penelitian terdahulu yang telah dilakukan. Dimana hasil investasi (investment result) berbanding lurus dengan kenaikan dana tabarru. Hal ini karena investasi yang ditanamkan pada masa mendatang akan menghasilkan profitabilitas (Nurcahya, 2012). Maka dari itu, saat investasi meningkat PT. AXA Mandiri Syariah akan mendapatkan hasil investasi yang bagus sehingga berimplikasi pada kenaikan dana tabarru.

\subsection{Perubahan Premium Income dan Investment Results serta Implikasinya terhadap Tabarru Fund Reserve}

Dana tabarru" yaitu pemberian sukarela dari seseorang kepada orang lain tanpa ganti rugi sehingga berpindahnya kepemilikan harta dari pemberi ke yang diberi dan diberikan secara ikhlas dengan menghadap ridho Allah kepada sesama peserta asuransi yang mendapat musibah (Sula, 2004). Dalam pengelolaan dana tabarru" diperlukan proses underwriting.

Manajemen underwriting dana tabarru menjadi patokan bagi perusahaan asuransi syariah dalam keberhasilannya mengelola dana peserta asuransi. Menurut (Fikri, 2009), hasil akhir dari pengelolaan underwriting yang baik tercermin dari tingginya underwriting dana tabarru pada periode tertentu sehingga berdampak pada kinerja perusahaan yang baik dan perusahaan asuransi dapat menyisihkan cadangan dana tabarru yang juga tinggi. Maka dari itu, hubungan antara pendapatan premi dan hasil investasi dengan cadangan dana tabbarû, tidak bisa dilepaskan dari penerapan fungsi manajemen underwriting yang dilakukan perusahaan asuransi syariah. Underwriting adalah proses seleksi berupa penilaian dan penglasifikasian risiko dari calon peserta untuk menentukan besaran premi/kontribusi yang harus dibayarkan yang mana hal ini dilakukan oleh tim penilai (underwriters) (Bayinah \& dkk, 2017).

Merujuk pada teori yang telah dipaparkan, pada pembahasan ini akan dijelaskan bahwa antara Premium Income dan Investment Result memiliki pengaruh yang signifikan terhadap Tabarru Fund Reserve

Tabel 6 Uji F

ANOVA $^{\mathrm{a}}$

\begin{tabular}{|rl|r|r|r|r|r|}
\hline Model & & Sum of Squares & df & Mean Square & \multicolumn{1}{c|}{ F } & Sig. \\
\hline \multirow{2}{*}{1} & Regression & 842095.294 & 2 & 421047.647 & 498074.594 & $.000^{\mathrm{b}}$ \\
& Residual & 14.371 & 17 & .845 & & \\
& Total & 842109.664 & 19 & & & \\
\hline
\end{tabular}

a. Dependent Variable: Tabarru_Fund_Reserve

b. Predictors: (Constant), Investment_Result, Premium_Income

Sumber: hasil output SPSS versi 20.0 
Tabel di atas merupakan hasil uji hipotesis secara simultan, F hitung yang didapatkan adalah 498074,594 dengan Sig 0,000. Ini memenuhi kriteria berpengaruh, karena 498074,594> 3,59 dan 0,551>0,05. Sehingga, disimpulkan secara simultan variabel inflasi dan ROI Du Pont tidak Berdasarkan perhitungan hasil SPSS For Windows 16.0 di atas diperoleh F hitung sebesar 0,649. Hal ini memenuhi syarat $F_{\text {hitung }}<F_{\text {tabel }}(0,649<4,74)$ dengan nilai taraf signifikansi sebesar 5\%. Dapat dirumuskan bahwa Ho diterima dan Ha ditolak. Hal ini berarti secara simultan variable Premium Income dan Investment Result memiliki pengaruh yang signifikan terhadap Tabarru Fund Reserve.

Selanjutnya kekuatan hubungan dan kontribusi pengaruh Premium Income dan Investment Result terhadap Tabarru Fund Reserve dapat dilihat pada tabel berikut:

\section{Tabel 7 Hasil Uji Korelasi dan Koefisien Determinasi}

Model Summary

\begin{tabular}{|c|c|c|c|c|}
\hline Model & $\mathrm{R}$ & $\mathrm{R}$ Square & Adjusted R Square & $\begin{array}{c}\text { Std. Error of the } \\
\text { Estimate }\end{array}$ \\
\hline 1 & $1.000^{\mathrm{a}}$ & 1.000 & 1.000 & .91943 \\
\hline
\end{tabular}

a. Predictors: (Constant), Investment_Result, Premium_Income

Sumber: hasil output SPSS versi 20.0

Berdasarkan perhitungan SPSS di atas dapat diketahui besarnya hubungan Premium Income dan Investment Result terhadap Tabarru Fund Reserve adalah 1,000 berada pada interval >0,999 yang berarti korelasi tersebut sangat kuat. Sedangkan, koefisien determinasi memiliki nilai 1,000 yang artinya terdapat hubungan antara Premium Income dan Investment Result terhadap Tabarru Fund Reserve sebesar 100\%.

Maka hasil penelitian ini sejalan dengan ketentuan PSAK di atas yang mana dana tabarru merupakan hasil akumulasi yang terbentuk dari akumulasi cadangan surplus/defisit dana tabarru, donasi, hasil investasi yang kemudian disalurkan kembali ke dalam dana tabarru. Oleh sebab itu, apabila premium income (pendapatan premi) meningkat dan investment results (hasil investasi) juga meningkat maka akan berdampak pada cadangan dana tabarru yang juga bertambah karena dana tabarru menjadi surplus dan banyak yang bisa di cadangkan.

Pada akhirnya, penelitian ini mendukung teori-teori yang sudah ada sebelumnya, juga mengembangkan penelitian sebelumnya. Hasil penelitian ini menemukan bahwa pada PT. AXA Mandiri Syariah pengaruh keduanya secara bersamaan sangat kuat dan memberikan pengaruh 100\% dalam peningkatan atau penurunan cadangan dana tabarru. Secara keseluruhan, hasil penelitian ini konsisten dengan penelitian (Fadlullah, 2014) yang hasil akhirnya secara bersamaan pendapatan premi dan hasil investasi berpengaruh signifikan. Selain itu juga mendukung hasil temuan penelitian (Supriyanto, 2015), dimana pendapatan premi, hasil investasi, dan klaim secara simultan berpengaruh signifikan. Namun penelitian ini kontra dengan hasil penelitian (Rahayu , 2017) yang hasil penelitiannya pendapatan premi dan hasil investasi tidak memiliki pengaruh signifikan.

\section{Kesimpulan}

Penelitian ini menghasilkan tiga kesimpulan bahwa perubahan premium income dan investment result pada PT. AXA Mandiri Syariah berimplilkasi pada tabarru fund reserve. Pertama, Premium Income mampu mempengaruhi Tabarru Fund Reserve PT. AXA Mandiri Syariah periode 20152019 dengan kontribusi pengaruh 100\%. Kedua, Investment Result juga mampu mempengaruh Tabarru Fund Reserve PT. AXA Mandiri Syariah periode 2015-2019 secara parsial dengan 
memberikan pengaruh sebesar 88,4\%. Dan terakhir, secara simultan Premium Income dan Investment Result berpengaruh signfikan Tabarru Fund Reserve PT. AXA Mandiri Syariah periode 2015-2019 dengan kontribusi pengaruh sebesar 100\%. Implikasi dari penelitian ini adalah perusahaan asuransi perlu meningkatkan Premium Income dan Investment Results, karena keduanya berpengaruh signifikan untuk meningkatkan Tabarru Fund Reserve

\section{Referensi}

Ali, A. H., Subekti, A., \& Wardana. (1996). Kamus Asuransi. Jakarta: Bumi Aksara.

Bayinah, A. N., \& dkk. (2017). Akuntansi Asuransi Syariah. Jakarta: Salemba Empat.

Fadlullah, A. (2014). Pengaruh Pendapatan Premi dan Hasil Investasi terhadap Cadangan Dana Tabarru pada PT. Asuransi Sinarmas Syariah . Jakarta: Perpustakaan Digital UIN Syarif Hidayatullah.

Fikri, M. A. (2009). Pengaruh Premi, Klaim, Hasil Investasi, dan Underwriting terhadap Laba Asuransi Jiwa (Studi Kasus PT. Asuransi Syariah Mubarakah). Universitas Pertanian Bogor: Tidak diterbitkan.

Firmansyah, H., \& Sobana, D. H. (2013). Bank dan Industri Kenangan Non Bank. Jakarta: PT. Naga Kusuma Media Kreatif.

Iqbal, M. (2005). Asuransi Umum Syariah Dalam Praktik. Jakarta: Gema Insani.

Lestari, M. (2017). Bank dan Lembaga Keuangan non Bank. Tanggerang Selatan: Universitas Terbuka.

Mulyawan, S. (2015). Manajemen Risiko. Bandung: Pustaka Setia.

Nurcahya, S. E. (2012). Analisis Pengarub Kontribusi Bruto, Reasuransi, Pembayaran Klaim dan Pendapatan Investasi Netto terhadap Surplus (Defisit) Underwriting Dana Tabarru' pada Perusabaan Asuransi Jiwa Syariah di Indonesia. Universitas Airlangga: Skripsi Tidak Diterbitkan.

Rahayu , S. (2017). Pengarub Pendapatan Premi dan Hasil Investasi terhadap Cadangan Dana Tabarru' pada PT. Asuransi AXA Mandiri Service periode 2009-2015. Bandung: Perpustakaan Digital UIN Sunan Gunung Djati .

Sula, M. S. (2004). Asuransi Syariah (Life and General) Konsep dan Operasional. Jakarta: Gema Insani Press.

Sumato, A. E., \& dkk. (2009). Solusi Berasuransi: Lebih Indah Syariah. Bandung: PT. Karya Kita.

Supriyanto, A. T. (2015). Pengarub Pendapatan Premi dan Hasil Investasi terhadap Cadangan Dana Tabarru pada Asuransi Syariah. Yogyakarta: Eprints UNY. 